\title{
Expanding the genetics of amyotrophic lateral sclerosis and frontotemporal dementia
}

\author{
Jennifer C Schymick*1,2 and Bryan J Traynor ${ }^{2}$
}

\begin{abstract}
Amyotrophic lateral sclerosis (ALS) is a fatal neurodegenerative disease characterized clinically by rapidly progressive paralysis leading ultimately to death from respiratory failure. It is now recognized that ALS and frontotemporal lobar degeneration (FTLD) form a clinical spectrum of disease with overlapping clinical, pathological and genetic features. This past year, the genetic causes of ALS have expanded to include mutations in the genes OPTN, VCP, and UBQLN2, and the hexanucleotide repeat expansion in C9ORF72. The C9ORF72 repeat expansion solidifies the notion that ALS and FTLD are phenotypic variations of a disease spectrum with a common molecular etiology. Furthermore, the C9ORF72 expansion is the genetic cause of a substantial portion of apparently sporadic ALS and FTLD cases, showing that genetics plays a clear role in sporadic disease. Here we describe the progress made in the genetics of ALS and FTLD, including a detailed look at how new insights brought about by C9ORF72 have both broadened and unified current concepts in neurodegeneration.
\end{abstract}

\section{Defining the overlap between ALS and FTLD: a necessary first step in unraveling the genetics of both conditions}

Amyotrophic lateral sclerosis (ALS) is a rapidly progressive, uniformly fatal, neurodegenerative disease. The annual incidence of ALS is reported to be 1.5 to 2.7 per 100,000 in Western countries [1,2]. There is currently no cure for ALS, and approximately 6,500 individuals die from the disease each year in the United States, making it the most common adult-onset form of motor neuron disease, and the third most common form of neurodegeneration [3]. Median age of symptom onset is

*Correspondence: schymicj@hs.uci.edu

'University of California Irvine School of Medicine, Irvine, CA 92697, USA Full list of author information is available at the end of the article between 65 and 67 years, meaning that ALS is often considered to be a disease associated with aging [4].

An important historical fact is that Jean Martin Charcot first defined ALS as a pure motor neuron disease [5]. Since then, the traditional view has been that cognition remains intact in the majority of ALS patients except for a small proportion who developed florid dementia (approximately $5 \%$ of cases). This view has only relatively recently been challenged and the current consensus is that ALS and frontotemporal lobar degeneration (FTLD) form part of a continuum of neurological disease: patients with familial and sporadic ALS exhibit signs of frontal lobe degeneration, including language dysfunction, changes in personality and executive function with relative sparing of memory [6-9]. Similarly, FTLD is complicated by motor neuron dysfunction in a significant proportion of patients. These observations directly led to diagnostic criteria categorizing cognitive and behavioral dysfunction in ALS [10].

The concept that ALS and FTLD represent a continuum of disease was further supported by neuropathological evidence concerning the abnormal protein aggregates observed in degenerating neurons. Initially, immunoreactive, ubiquitin-positive neuronal inclusions were identified in ALS and FTLD and provided a first clue of a shared pathogenic mechanism between these conditions. Then, in 2006, the TAR DNA-binding protein $43 \mathrm{kDa}$ (TDP-43) was discovered to be the main component of the ubiquinated inclusions [11]. In 2009, aggregations of the fused in sarcoma protein (FUS) were demonstrated in a subset of ALS and FTLD patients with TDP-43-negative neuronal inclusions (representing approximately 5\% of cases) [12]. Following these discoveries, it was proposed that ALS and FTLD form a clinicopathological spectrum of TDP-43 and FUS proteinopathies [13], though it is also noteworthy that approximately $40 \%$ of FTLD cases are tauopathies and there is currently no known relationship between such cases and ALS.

Why is this overlap between ALS and FTLD important to our discussion about genetics? The realization that ALS and FTLD are essentially two sides to the same neurodegenerative coin allowed the identification of several families in which the conditions co-existed. The 
large number of affected individuals available for study in these ALS/FTLD families increased the linkage value of these families, and consequently their power to find new genes.

\section{State of play of ALS and FTLD genetics before the C9ORF72 discovery}

Population-based epidemiological studies show that approximately $5 \%$ of ALS is familial in nature, with a predominantly autosomal dominant pattern of inheritance [1]. The remaining $95 \%$ of cases do not have a family history of ALS, and appear to occur sporadically throughout the community. The clinical characteristics of familial and sporadic ALS are nearly indistinguishable, and it has long been hoped that understanding familial ALS would shed light on the fundamental processes underlying the pathogenesis of the more common sporadic form of the disease. At least that was the theory...

Substantial progress had been made over the past 20 years in our understanding of the genetic factors contributing to familial ALS. These include the identification of mutations in the SOD1 gene in 1993, which account for approximately $12 \%$ of familial ALS cases in population-based studies $[14,15]$. There was then a long hiatus until mutations in the TARDBP gene, which encodes the TDP-43 protein, were found in 2008 [16]. This was followed quickly by the discovery of mutations in the FUS gene as the cause of chromosome 16-linked ALS $[17,18]$. Each of these genes accounted for approximately $4 \%$ of familial ALS cases.

More recently, the pace of genetic discovery has accelerated due to advances in genomic sequencing technologies. This led to the discovery of additional familial ALS genes, including OPTN, VCP, and UBQLN2 [19-21]. The discovery of $V C P$ was particularly important in that regard, as it was previously known to cause FTLD, further strengthening the genetic link between these two neurodegenerative disorders. Although the discovery of each of these genes represented a quantum leap forward in our understanding of the pathogenic pathways underlying motor neuron degeneration, these mutations together only accounted for a quarter of familial ALS cases. Clearly, additional genes remained to be found.

But how well did these findings in familial ALS translate to the more common sporadic form of the disease? Truth be told, the genetics of sporadic ALS were proving much more difficult to unravel [22,23]. Mutations in the known familial ALS genes - SOD1, FUS, TDP-43, and $V C P$ - occur only rarely in sporadic cases [15,24-26]. As a consequence, the prevailing hypothesis was that environmental factors were more relevant in the sporadic form of the disease. Nevertheless, advances in genomic technology made it far more attractive to chase the genetics of sporadic ALS, rather than focusing on proving environmental hypotheses [27]. Research in other neurological diseases, most notably Parkinson's disease, confirmed that genetics could be a key driving force in neurodegeneration [28]. This view was reinforced by the occasional finding of de novo mutations of known familial ALS genes in young patients with sporadic ALS [29-31].

\section{Identification of chromosome 9 as an important player in ALS and FTLD}

The long arm of chromosome 9 was initially linked to ALS and FTLD in a 2000 Journal of the American Medical Association paper [32]. This initial locus was later refined to involve the short arm of chromosome 9 in 2006 with the publication of two papers reporting linkage to the region in large Dutch and Scandinavian ALS-FTLD families $[33,34]$. The initial genetic area defined by these studies was further shortened to a 7.1 MB region by the publication of several additional linkage studies [35-38].

From an early stage it was apparent that chromosome 9p21 was an important locus in ALS and FTLD, as it appeared to underlie a large proportion of familial ALS cases. Interest was further raised when ALS and FTLD genome-wide association studies consistently found an association signal within the chromosome 9 locus [3942]. These studies narrowed the area of interest to a relatively small $232 \mathrm{~kb}$ region of the genome located at chromosome 9p21, containing only three genes $(M O B L K 2 B$, IFNK, and C9ORF72). Bizarrely, the underlying mutation was proving difficult to find despite the small size of the region of interest. As time went by, the whole locus looked increasingly intractable and a 'Holy Grail' aura developed around it.

Our own genome-wide association study of ALS in Finland identified a 42-SNP founder haplotype that segregated within ALS/FTLD families. Informed by that observation, we believed from an early stage that the chromosome 9p21 locus was due to a founder mutation $[39,43]$, though this notion was rebuffed by other groups studying the same region [40].

\section{C9ORF72 revealed}

Ultimately, a massive hexanucleotide repeat expansion in the C9ORF72 gene was found to be the mutation underlying chromosome 9p21. Back-to-back publications appeared in the October 2011 edition of Neuron revealing the causative mutation to be a massively expanded GGGGCC hexanucleotide repeat expansion [44,45]. This expansion accounted for an exceptionally large proportion of both familial ALS and FTLD, as well as a large proportion of sporadic ALS and FTLD. These publications represented the culmination of three years of intense national and international collaboration [46]. The finding was subsequently replicated by independent groups in different populations $[47,48]$. 
Only a short period of time has passed since the discovery of the C9ORF72 repeat expansion, but already certain aspects are becoming clear. The pathogenic expansion on chromosome $9 \mathrm{p} 21$ is by far the most frequent cause of ALS and FTLD identified to date, being at least twice as common as SOD1 mutations in ALS, and as PGRN mutations in FTLD. The discovery of the hexanucleotide repeat expansion increased the proportion of familial ALS that was explained from one-quarter to nearly two-thirds. It also showed that genetics plays a major role in apparently sporadic ALS and FTLD, thereby unifying the two major forms of the disease: in a large cohort of white Europeans, Americans, and Australians the C9ORF72 repeat was identified in approximately $6 \%$ of both sporadic ALS and FTLD cases [49]. Patients with pure ALS, pure FTLD, or ALS-FTLD have 700 to 1,600 repeats that may be up to $10 \mathrm{~kb}$ in length, whereas people without these diseases have fewer than 24 repeats $[44,45]$.

\section{But what does C9ORF72 do?}

The key question among researchers at the moment is 'what is the normal function of C9ORF72' and 'by what cellular mechanism does the pathogenic repeat expansion lead to neurodegeneration?' C9ORF72 encodes a highly conserved, 481 (full-length) amino acid protein. The protein has no discernable domains, and consequently, little is known about its function. There are three reported splice variants with the pathogenic repeat expansion variably lying within the promoter or first intron of the different transcripts $[44,45]$.

Different mechanisms of disease can be postulated for any of the repeat expansion disorders, including loss of function, gain of function due to abnormal RNA toxicity, or gain of function due to abnormal protein toxicity [50]. At the present time, it is unclear which of these mechanisms is operating in C9ORF72-ALS, and there are conflicting data for each: the location of the repeat directly within the promoter of the long C9ORF72 transcript suggests the possibility that the expansion alters C9ORF72 expression, at least of this isoform. Altered C9ORF72 transcription is supported by both original Neuron papers, which identified reduced expression of the longer mRNA isoforms in brain $[44,45]$. On the other hand, most of the autopsy-confirmed mutation carrier patients had TDP-43 inclusions in brain or spinal cord, indicating that abnormal protein accumulation is important, regardless of the initiating cellular mechanism $[51,52]$. Furthermore, the RNA inclusions reported in the original DeJesus-Hernandez et al. paper [44] suggest that toxic RNA species generated from the expansion may be important. So far these initial findings have proven difficult to replicate, perhaps because of the technical difficulties inherent in in situ hybridization $[53,54]$.

\section{Clinical characteristics of C9ORF72-associated disease}

Clinically, C9ORF72 expansion cases with motor neuron dysfunction show features of classical ALS with a relatively rapidly progression. Disease duration was six months shorter in ALS cases with C9ORF72 expansions compared with the non-C9ORF72 ALS cases [51]. Bulbar-onset disease was also more common in patients with the C9ORF72 mutation compared to non-C9ORF72 ALS cases [55]. C9ORF72 ALS patients were also more likely to be female, have a family history of disease, and had a slightly younger age at onset than the general ALS population [47].

The clinical overlap between ALS and FTLD is pronounced in C9ORF72 expansion carriers. Patients with ALS and a C9ORF72 mutation were more likely to have a relative with another neurodegenerative disorder, most commonly FTLD, and approximately $60 \%$ of ALS patients with the expansion have a family history of dementia. Dementia was also significantly more common in probands with the C9ORF72 mutation compared with SOD1 mutation carriers [56]. These cases more commonly presented with behavioral variant FTLD. Furthermore, over half of FTLD probands with the pathogenic expansion were reported to have a personal or a family history of ALS.

Several studies have identified other neurodegenerative processes in C9ORF72 carriers, thereby widening the clinical spectrum beyond ALS and FTLD. In a study by Boeve et al. [57], parkinsonism was present in approximately one-third of subjects, all of whom had behavioral variant FTLD or ALS-FTLD. Patients with Alzheimerlike amnestic syndromes with prominent hippocampal sclerosis were also identified $[52,58]$. In a separate study, $38 \%$ of patients with C9ORF72 mutations presented with psychosis, with an additional 28\% exhibiting paranoid, deluded or irrational thinking [59]. These findings suggest that the C9ORF72 expansion may contribute to a broad spectrum of neurodegeneration and psychiatric disorders.

Evidence for incomplete penetrance has been seen in multiple ALS, FTLD, and ALS-FTLD pedigrees. In our own analysis of 604 cases, the pathogenic expansion was non-penetrant in carriers younger than 35 years of age, $50 \%$ penetrant by 58 years, and almost fully penetrant by 80 years [49].

Haplotype analysis has suggested that every patient identified to date carrying the pathogenic GGGGCC repeat expansion also shares the Finnish founder risk haplotype, at least in part. Analysis of the haplotype suggests that predisposing or pathogenic hexanucleotide repeat expansion in C9ORF72 might have occurred on a single occasion in human history 1,500 years ago, and subsequently disseminated throughout the world $[39,43,49]$. 
In contrast to this 'single expansion' hypothesis, it is also possible that the C9ORF72 hexanucleotide repeat is inherently unstable and prone to spontaneous expansion across generations. Under this model, expansions occur on a predisposing haplotype, leading to the occurrence of apparent sporadic cases and anticipation within families with disease. Such a mechanism is known to exist in spinocerebellar ataxia type 8 [60]. Seven-to-ten year anticipation has been noted by several studies in younger generations, and would support this 'recurring event' hypothesis [55,57]. However, proof of this hypothesis will depend on the identification of a pathogenic repeat expansion in an affected offspring that is not present in either parent.

\section{Conclusions: much done, but also much to do}

The past year has seen a dramatic growth in our knowledge of the genetics of ALS with the discovery of mutations in OPTN, VCP, and UBQLN2, and the discovery of the repeat expansion in C9ORF72. Among them, the C9ORF72 hexanucleotide expansion is now recognized as the most frequent cause of familial ALS and FTLD, and has shown that genetics plays an important role in sporadic disease. In addition, the C9ORF72 expansion clearly provides a shared molecular etiology between ALS and FTLD. This discovery is expected to have a large impact on the direction of future research and clinical trials.

Despite this remarkable progress, a number of important questions remain unanswered. First, how many repeats are required for the expansion to precipitate neurodegeneration? Second, does repeat length variation contribute to the age of disease onset, the speed of disease progression, or even drive whether a patient will present with an ALS or FTLD phenotype? Third, do additional factors such as variation within the repeat expansion, variation in local gene expression, or modifiers elsewhere in the genome influence the disease? Fourth, defining the mechanism by which the repeat expansion leads to selective neuronal degeneration is key in understanding the disease, and an essential first step in the development of therapies aimed at modifying disease progression. And finally, what are the genes responsible for the other one-third of familial ALS and the other $90 \%$ of sporadic disease? Expanding our knowledge of the genetics of ALS and FTLD is a necessary step to a more complete understanding of the pathogenic pathways underlying these fatal neurodegenerative disorders.

\section{Abbreviations}

ALS, amyotrophic lateral sclerosis; FTLD, frontotemporal lobar degeneration.

\section{Competing interests}

Bryan Traynor has a patent pending on the diagnostic and therapeutic implications of the C9ORF72 hexanucleotide expansion discovery.

\section{Acknowledgements}

This work was supported by the Intramural Research Programs of the NIH, National Institute on Aging (Z01-AG000949-02).

\section{Author details}

'University of California Irvine School of Medicine, Irvine, CA 92697, USA ${ }^{2}$ Neuromuscular Diseases Research Unit, Laboratory of Neurogenetics, NIA, $\mathrm{NIH}$, Bethesda, MD 20892, USA.

Published: 26 July 2012

\section{References}

1. Logroscino G, Traynor BJ, Hardiman O, Chió A, Mitchell D, Swingler RJ, Millul A, Benn E, Beghi E: Incidence of amyotrophic lateral sclerosis in Europe. J Neurol Neurosurg Psychiatry 2009, 81:385-390.

2. Cronin S, Hardiman O, Traynor BJ: Ethnic variation in the incidence of ALS: a systematic review. Neurology 2007, 68:1002-1007.

3. Hirtz D, Thurman DJ, Gwinn-Hardy K, Mohamed M, Chaudhuri AR, Zalutsky R: How common are the "common" neurologic disorders? Neurology 2007, 68:326-337.

4. Traynor BJ, Codd MB, Corr B, Forde C, Frost E, Hardiman O: Incidence and prevalence of ALS in Ireland, 1995-1997: a population-based study. Neurology 1999, 52:504-509.

5. Charcot JM: Lectures on Diseases of the Central Nervous System. London: The New Sydenham Society; 1881

6. Ringholz GM, Appel SH, Bradshaw M, Cooke NA, Mosnik DM, Schulz PE: Prevalence and patterns of cognitive impairment in sporadic ALS. Neurology 2005, 65:586-590.

7. Lomen-Hoerth C, Murphy J, Langmore S, Kramer JH, Olney RK, Miller B: Are amyotrophic lateral sclerosis patients cognitively normal? Neurology 2003, 60:1094-1097.

8. Murphy J, Henry R, Lomen-Hoerth C: Establishing subtypes of the continuum of frontal lobe impairment in amyotrophic lateral sclerosis. Arch Neurol 2007, 64:330-334.

9. Phukan J, Elamin M, Bede P, Jordan N, Gallagher L, Byrne S, Lynch C, Pender N, Hardiman O: The syndrome of cognitive impairment in amyotrophic lateral sclerosis: a population-based study. J Neurol Neurosurg Psychiatry 2012, 83:102-108.

10. Strong MJ, Grace GM, Freedman M, Lomen-Hoerth C, Woolley S, Goldstein LH, Murphy J, Shoesmith C, Rosenfeld J, Leigh PN, Bruijn L, Ince P, Figlewicz D: Consensus criteria for the diagnosis of frontotemporal cognitive and behavioural syndromes in amyotrophic lateral sclerosis. Amyotroph Lateral Scler 2009, 10:131-146.

11. Neumann M, Sampathu DM, Kwong LK, Truax AC, Micsenyi MC, Chou TT, Bruce J, SchuckT, Grossman M, Clark CM, McCluskey LF, Miller BL, Masliah E, Mackenzie IR, Feldman H, Feiden W, Kretzschmar HA, Trojanowski JQ, Lee VM: Ubiquitinated TDP-43 in frontotemporal lobar degeneration and amyotrophic lateral sclerosis. Science 2006, 314:130-133.

12. Neumann M, Rademakers $\mathrm{R}$, Roeber S, Baker M, Kretzschmar HA, Mackenzie IR: A new subtype of frontotemporal lobar degeneration with FUS pathology. Brain 2009, 132:2922-2931.

13. Mackenzie IR, Rademakers R, Neumann M: TDP-43 and FUS in amyotrophic lateral sclerosis and frontotemporal dementia. Lancet Neurol 2010, 9:995-1007.

14. Rosen DR: Mutations in Cu/Zn superoxide dismutase gene are associated with familial amyotrophic lateral sclerosis. Nature 1993, 364:362.

15. Chiò A, Traynor BJ, Lombardo F, Fimognari M, Calvo A, Ghiglione P, Mutani R, Restagno G: Prevalence of SOD1 mutations in the Italian ALS population. Neurology 2008, 70:533-537.

16. Sreedharan J, Blair IP, Tripathi VB, Hu X, Vance C, Rogelj B, Ackerley S, Durnall JC, Williams KL, Buratti E, Baralle F, de Belleroche J, Mitchell JD, Leigh PN, Al-Chalabi A, Miller CC, Nicholson G, Shaw CE: TDP-43 mutations in familial and sporadic amyotrophic lateral sclerosis. Science 2008, 319:1668-1672.

17. Kwiatkowski TJ Jr, Bosco DA, Leclerc AL, Tamrazian E, Vanderburg CR, Russ C, Davis A, Gilchrist J, Kasarskis EJ, Munsat T, Valdmanis P, Rouleau GA, Hosler BA Cortelli P, de Jong PJ, Yoshinaga Y, Haines JL, Pericak-Vance MA, Yan J, Ticozzi N, Siddique T, McKenna-Yasek D, Sapp PC, Horvitz HR, Landers JE, Brown RH $\mathrm{Jr}$ : Mutations in the FUS/TLS gene on chromosome 16 cause familial amyotrophic lateral sclerosis. Science 2009, 323:1205-1208.

18. Vance C, Rogelj B, Hortobágyi T, De Vos KJ, Nishimura AL, Sreedharan J, Hu X, Smith B, Ruddy D, Wright P, Ganesalingam J, Williams KL, Tripathi V, Al-Saraj S, 
Al-Chalabi A, Leigh PN, Blair IP, Nicholson G, de Belleroche J, Gallo JM, Miller CC, Shaw CE: Mutations in FUS, an RNA processing protein, cause familial amyotrophic lateral sclerosis type 6. Science 2009, 323:1208-1211.

19. Maruyama H, Morino H, Ito H, Izumi Y, Kato H, Watanabe Y, Kinoshita Y, Kamada M, Nodera H, Suzuki H, Komure O, Matsuura S, Kobatake K, Morimoto N, Abe K, Suzuki N, Aoki M, Kawata A, Hirai T, Kato T, Ogasawara K, Hirano A, Takumi T, Kusaka H, Hagiwara K, Kaji R, Kawakami H: Mutations of optineurin in amyotrophic lateral sclerosis. Nature 2010, 465:223-226.

20. Johnson JO, Mandrioli J, Benatar M, Abramzon Y, Van Deerlin VM, Trojanowski JQ, Gibbs JR, Brunetti M, Gronka S, Wuu J, Ding J, McCluskey L, Martinez-Lage M, Falcone D, Hernandez DG, Arepalli S, Chong S, Schymick JC, Rothstein J, Landi F, Wang YD, Calvo A, Mora G, Sabatelli M, Monsurrò MR, Battistini S, Salvi F, Spataro R, Sola P, Borghero G, et al:: Exome sequencing reveals VCP mutations as a cause of familial ALS. Neuron 2010, 68:857-864.

21. Deng HX, Chen W, Hong ST, Boycott KM, Gorrie GH, Siddique N, Yang Y, Fecto F, Shi Y, Zhai H, Jiang H, Hirano M, Rampersaud E, Jansen GH, Donkervoort S, Bigio EH, Brooks BR, Ajroud K, Sufit RL, Haines JL, Mugnaini E, Pericak-Vance MA, Siddique T: Mutations in UBQLN2 cause dominant X-linked juvenile and adult-onset ALS and ALS/dementia. Nature 2011, 477:211-215.

22. Schymick JC, Talbot K, Traynor BJ: Genetics of sporadic amyotrophic lateral sclerosis. Hum Mol Genet 2007, 16:R233-242.

23. Chiò A, Schymick JC, Restagno G, Scholz SW, Lombardo F, Lai SL, Mora G, Fung HC, Britton A, Arepalli S, Gibbs JR, Nalls M, Berger S, Kwee LC, Oddone EZ, Ding J, Crews C, Rafferty I, Washecka N, Hernandez D, Ferrucci L, Bandinelli S, Guralnik J, Macciardi F, Torri F, Lupoli S, Chanock SJ, Thomas G, Hunter DJ, Gieger C, et al:: A two-stage genome-wide association study of sporadic amyotrophic lateral sclerosis. Hum Mol Genet 2009, 18:1524-1532.

24. Lai SL, Abramzon Y, Schymick JC, Stephan DA, Dunckley T, Dillman A, Cookson M, Calvo A, Battistini S, Giannini F, Caponnetto C, Mancardi GL, Spataro R, Monsurro MR, Tedeschi G, Marinou K, Sabatelli M, Conte A, Mandrioli J, Sola P, Salvi F, Bartolomei I, Lombardo F; ITALSGEN Consortium, Mora G, Restagno G, Chiò A, Traynor BJ: FUS mutations in sporadic amyotrophic lateral sclerosis. Neurobiol Aging 2011, 32:550.e1-4.

25. Guerreiro RJ, Schymick JC, Crews C, Singleton A, Hardy J, Traynor BJ: TDP-43 is not a common cause of sporadic amyotrophic lateral sclerosis. PLOS One 2008, 3:e2450.

26. Abramzon Y, Johnson JO, Scholz SW, Taylor JP, Brunetti M, Calvo A, Mandrioli J, Benatar M, Mora G, Restagno G, Chiò A, Traynor BJ: Valosin-containing protein mutations in sporadic amyotrophic lateral sclerosis. Neurobiol Aging 2012, 33:2231.e1-6.

27. Traynor BJ, Singleton AB: Nature versus nurture: death of a dogma, and the road ahead. Neuron 2010, 68:196-200.

28. International Parkinson Disease Genomics Consortium, Nalls MA, Plagnol V, Hernandez DG, Sharma M, Sheerin UM, Saad M, Simón-Sánchez J, Schulte C, Lesage S, Sveinbjörnsdóttir S, Stefánsson K, Martinez M, Hardy J, Heutink P, Brice A, Gasser T, Singleton AB, Wood NW: Imputation of sequence variants for identification of genetic risks for Parkinson's disease: a meta-analysis of genome-wide association studies. Lancet 2011, 377:641-649.

29. Alexander MD, Traynor BJ, Miller N, Corr B, Frost E, McQuaid S, Brett FM, Green A, Hardiman O: "True" sporadic ALS associated with a novel SOD-1 mutation. Ann Neurol 2002, 52:680-683.

30. Chiò A, Calvo A, Moglia C, Ossola I, Brunetti M, Sbaiz L, Lai SL, Abramzon Y, Traynor BJ, Restagno G: A de novo missense mutation of the FUS gene in a "true" sporadic ALS case. Neurobiol Aging 2011, 32:553.e23-26.

31. DeJesus-Hernandez M, Kocerha J, Finch N, Crook R, Baker M, Desaro P, Johnston A, Rutherford N, Wojtas A, Kennelly K, Wszolek ZK, Graff-Radford N, Boylan K, Rademakers R: De novo truncating FUS gene mutation as a cause of sporadic amyotrophic lateral sclerosis. Hum Mutat 2010, 31:E1377-1389.

32. Hosler BA, Siddique T, Sapp PC, Sailor W, Huang MC, Hossain A, Daube JR, Nance M, Fan C, Kaplan J, Hung WY, McKenna-Yasek D, Haines JL, PericakVance MA, Horvitz HR, Brown RH Jr: Linkage of familial amyotrophic lateral sclerosis with frontotemporal dementia to chromosome 9q21-q22. JAMA 2000, 284:1664-1669.

33. Morita M, Al-Chalabi A, Andersen PM, Hosler B, Sapp P, Englund E, Mitchell JE, Habgood JJ, de Belleroche J, Xi J, Jongjaroenprasert W, Horvitz HR, Gunnarsson LG, Brown RH Jr: A locus on chromosome 9p confers susceptibility to ALS and frontotemporal dementia. Neurology 2006, 66:839-844

34. Vance C, Al-Chalabi A, Ruddy D, Smith BN, Hu X, Sreedharan J, Siddique T, Schelhaas HJ, Kusters B, Troost D, Baas F, de Jong V, Shaw CE: Familial amyotrophic lateral sclerosis with frontotemporal dementia is linked to a locus on chromosome 9p13.2-21.3. Brain 2006, 129:868-876.

35. Boxer AL, Mackenzie IR, Boeve BF, Baker M, Seeley WW, Crook R, Feldman H, Hsiung GY, Rutherford N, Laluz V, Whitwell J, Foti D, McDade E, Molano J, Karydas A, Wojtas A, Goldman J, Mirsky J, Sengdy P, Dearmond S, Miller BL, Rademakers R: Clinical, neuroimaging and neuropathological features of a new chromosome 9p-linked FTD-ALS family. J Neurol Neurosurg Psychiatry 2011, 82:196-203.

36. Le Ber I, Camuzat A, Berger E, Hannequin D, Laquerrière A, Golfier V, Seilhean D, Viennet G, Couratier P, Verpillat P, Heath S, Camu W, Martinaud O, Lacomblez L, Vercelletto M, Salachas F, Sellal F, Didic M, Thomas-Anterion C, Puel M, Michel BF, Besse C, Duyckaerts C, Meininger V, Campion D, Dubois B, Brice A; French Research Network on FTD/FTD-MND: Chromosome 9plinked families with frontotemporal dementia associated with motor neuron disease. Neurology 2009, 72:1669-1676.

37. Luty AA, Kwok JB, Thompson EM, Blumbergs P, Brooks WS, Loy CT, DobsonStone C, Panegyres PK, Hecker J, Nicholson GA, Halliday GM, Schofield PR: Pedigree with frontotemporal lobar degeneration--motor neuron disease and Tar DNA binding protein- 43 positive neuropathology: genetic linkage to chromosome 9. BMC Neurol 2008, 8:32.

38. Valdmanis PN, Dupre N, Bouchard JP, Camu W, Salachas F, Meininger V, Strong M, Rouleau GA: Three families with amyotrophic lateral sclerosis and frontotemporal dementia with evidence of linkage to chromosome $9 p$. Arch Neurol 2007, 64:240-245.

39. Laaksovirta H, Peuralinna T, Schymick JC, Scholz SW, Lai SL, Myllykangas L, Sulkava R, Jansson L, Hernandez DG, Gibbs JR, Nalls MA, Heckerman D, Tienari PJ, Traynor BJ: Chromosome 9p21 in amyotrophic lateral sclerosis in Finland: a genome-wide association study. Lancet Neurol 2010, 9:978-985.

40. Shatunov A, Mok K, Newhouse S, Weale ME, Smith B, Vance C, Johnson L, Veldink JH, van Es MA, van den Berg LH, Robberecht W, Van Damme P, Hardiman O, Farmer AE, Lewis CM, Butler AW, Abel O, Andersen PM, Fogh I, Silani V, Chiò A, Traynor BJ, Melki J, Meininger V, Landers JE, McGuffin P, Glass JD, Pall H, Leigh PN, Hardy J, et al.: Chromosome 9p21 in sporadic amyotrophic lateral sclerosis in the UK and seven other countries: a genome-wide association study. Lancet Neurol 2010, 9:986-994.

41. Van Deerlin VM, Sleiman PM, Martinez-Lage M, Chen-Plotkin A, Wang LS, Graff-Radford NR, Dickson DW, Rademakers R, Boeve BF, Grossman M, Arnold SE, Mann DM, Pickering-Brown SM, Seelaar H, Heutink P, van Swieten JC, Murrell JR, Ghetti B, Spina S, Grafman J, Hodges J, Spillantini MG, Gilman S, Lieberman AP, Kaye JA, Woltjer RL, Bigio EH, Mesulam M, Al-Sarraj S, Troakes C, et al:: Common variants at 7p21 are associated with frontotemporal lobar degeneration with TDP-43 inclusions. Nat Genet 2010, 42:234-239.

42. van Es MA, Veldink JH, Saris CG, Blauw HM, van Vught PW, Birve A, Lemmens R, Schelhaas HJ, Groen EJ, Huisman MH, van der Kooi AJ, de Visser M, Dahlberg C, Estrada K, Rivadeneira F, Hofman A, Zwarts MJ, van Doormaal PT, Rujescu D, Strengman E, Giegling I, Muglia P, Tomik B, Slowik A, Uitterlinden AG, Hendrich C, Waibel S, Meyer T, Ludolph AC, Glass JD, et al:: Genome-wide association study identifies 19p13.3 (UNC13A) and 9p21.2 as susceptibility loci for sporadic amyotrophic lateral sclerosis. Nat Genet 2009, 41:1083-1087.

43. Mok K, Traynor BJ, Schymick J, Tienari PJ, Laaksovirta H, Peuralinna T, Myllykangas L, Chiò A, Shatunov A, Boeve BF, Boxer AL, DeJesus-Hernandez M, Mackenzie IR, Waite A, Williams N, Morris HR, Simón-Sánchez J, van Swieten JC, Heutink P, Restagno G, Mora G, Morrison KE, Shaw PJ, Rollinson PS, Al-Chalabi A, Rademakers R, Pickering-Brown S, Orrell RW, Nalls MA, Hardy $\mathrm{J}$ : Chromosome 9 ALS and FTD locus is probably derived from a single founder. Neurobiol Aging 2012, 33:209.e3-8.

44. DeJesus-Hernandez M, Mackenzie IR, Boeve BF, Boxer AL, Baker M, Rutherford NJ, Nicholson AM, Finch NA, Flynn H, Adamson J, Kouri N, Wojtas A, Sengdy P, Hsiung GY, Karydas A, Seeley WW, Josephs KA, Coppola G, Geschwind DH, Wszolek ZK, Feldman H, Knopman DS, Petersen RC, Miller BL, Dickson DW, Boylan KB, Graff-Radford NR, Rademakers R: Expanded GGGGCC hexanucleotide repeat in noncoding region of C9ORF72 causes chromosome 9p-linked FTD and ALS. Neuron 2011, 72:245-256.

45. Renton AE, Majounie E, Waite A, Simón-Sánchez J, Rollinson S, Gibbs JR, Schymick JC, Laaksovirta H, van Swieten JC, Myllykangas L, Kalimo H, Paetau A, Abramzon Y, Remes AM, Kaganovich A, Scholz SW, Duckworth J, Ding J, Harmer DW, Hernandez DG, Johnson JO, Mok K, Ryten M, Trabzuni D, Guerreiro RJ, Orrell RW, Neal J, Murray A, Pearson J, Jansen IE, et al.: Ahexanucleotide repeat expansion in C9ORF72 is the cause of chromosome 9p21-linked ALS-FTD. Neuron 2011, 72:257-268.

46. Traynor BJ: Road to the chromosome 9p-linked ALS/FTD locus. J Neurol 
Neurosurg Psychiatry 2012, 83:356-357.

47. Byrne S, Elamin M, Bede P, Shatunov A, Walsh C, Corr B, Heverin M, Jordan N, Kenna K, Lynch C, McLaughlin RL, Iyer PM, O'Brien C, Phukan J, Wynne B, Bokde AL, Bradley DG, Pender N, Al-Chalabi A, Hardiman O: Cognitive and clinical characteristics of patients with amyotrophic lateral sclerosis carrying a C9orf72 repeat expansion: a population-based cohort study. Lancet Neurol 2012, 11:232-240.

48. Gijselinck I, Van Langenhove T, van der Zee J, Sleegers K, Philtjens S, Kleinberger G, Janssens J, Bettens K, Van Cauwenberghe C, Pereson S, Engelborghs S, Sieben A, De Jonghe P, Vandenberghe R, Santens P, De Bleecker J, Maes G, Bäumer V, Dillen L, Joris G, Cuijt I, Corsmit E, Elinck E, Van Dongen J, Vermeulen S, Van den Broeck M, Vaerenberg C, Mattheijssens M, Peeters K, Robberecht W, et al:: A C9orf72 promoter repeat expansion in a Flanders-Belgian cohort with disorders of the frontotemporal lobar degeneration-amyotrophic lateral sclerosis spectrum: a gene identification study. Lancet Neurol 2012, 11:54-65.

49. Majounie E, Renton AE, Mok K, Dopper EG, Waite A, Rollinson S, Chiò A, Restagno G, Nicolaou N, Simon-Sanchez J, van Swieten JC, Abramzon Y, Johnson JO, Sendtner M, Pamphlett R, Orrell RW, Mead S, Sidle KC, Houlden H, Rohrer JD, Morrison KE, Pall H, Talbot K, Ansorge O; Chromosome 9-ALS/ FTD Consortium; French research network on FTLD/FTLD/ALS; ITALSGEN Consortium, Hernandez DG, Arepalli S, Sabatelli M, et al.: Frequency of the C9orf72 hexanucleotide repeat expansion in patients with amyotrophic lateral sclerosis and frontotemporal dementia: a cross-sectional study. Lancet Neurol 2012, 11:323-330.

50. La Spada AR, Taylor JP: Repeat expansion disease: progress and puzzles in disease pathogenesis. Nat Rev Genet 2010, 11:247-258.

51. Cooper-Knock J, Hewitt C, Highley JR, Brockington A, Milano A, Man S, Martindale J, Hartley J, Walsh T, Gelsthorpe C, Baxter L, Forster G, Fox M, Bury J, Mok K, McDermott CJ, Traynor BJ, Kirby J, Wharton SB, Ince PG, Hardy J, Shaw PJ: Clinico-pathological features in amyotrophic lateral sclerosis with expansions in C9ORF72. Brain 2012, 135:751-764.

52. Murray ME, DeJesus-Hernandez M, Rutherford NJ, Baker M, Duara R, GraffRadford NR, Wszolek ZK, Ferman TJ, Josephs KA, Boylan KB, Rademakers R, Dickson DW: Clinical and neuropathologic heterogeneity of C9FTD/ALS associated with hexanucleotide repeat expansion in C9ORF72. Acta Neuropathol 2011, 122:673-690.

53. Simón-Sánchez J, Dopper EG, Cohn-Hokke PE, Hukema RK, Nicolaou N, Seelaar H, de Graaf JR, de Koning I, van Schoor NM, Deeg DJ, Smits M, Raaphorst J, van den Berg LH, Schelhaas HJ, De Die-Smulders CE, MajoorKrakauer D, Rozemuller AJ, Willemsen R, Pijnenburg YA, Heutink P, van Swieten JC: The clinical and pathological phenotype of C9ORF72 hexanucleotide repeat expansions. Brain 2012, 135:723-735.
54. Jiang H, Mankodi A, Swanson MS, Moxley RT, Thornton CA: Myotonic dystrophy type 1 is associated with nuclear foci of mutant RNA, sequestration of muscleblind proteins and deregulated alternative splicing in neurons. Hum Mol Genet 2004, 13:3079-3088.

55. Chiò A, Borghero G, Restagno G, Mora G, Drepper C, Traynor BJ, Sendtner M, Brunetti M, Ossola I, Calvo A, Pugliatti M, Sotgiu MA, Murru MR, Marrosu MG, Marrosu F, Marinou K, Mandrioli J, Sola P, Caponnetto C, Mancardi G, Mandich P, La Bella V, Spataro R, Conte A, Monsurrò MR, Tedeschi G, Pisano F, Bartolomei I, Salvi F, Lauria Pinter G, et al: Clinical characteristics of patients with familial amyotrophic lateral sclerosis carrying the pathogenic GGGGCC hexanucleotide repeat expansion of C9ORF72. Brain 2012, 135:784-793

56. Stewart H, Rutherford NJ, Briemberg H, Krieger C, Cashman N, Fabros M, Baker M, Fok A, DeJesus-Hernandez M, Eisen A, Rademakers R, Mackenzie IR: Clinical and pathological features of amyotrophic lateral sclerosis caused by mutation in the C9ORF72 gene on chromosome 9p. Acta Neuropathol 2012, 123:409-417.

57. Boeve BF, Boylan KB, Graff-Radford NR, DeJesus-Hernandez M, Knopman DS, Pedraza O, Vemuri P, Jones D, Lowe V, Murray ME, Dickson DW, Josephs KA, Rush BK, Machulda MM, Fields JA, Ferman TJ, Baker M, Rutherford NJ, Adamson J, Wszolek ZK, Adeli A, Savica R, Boot B, Kuntz KM, Gavrilova R, Reeves A, Whitwell J, Kantarci K, Jack CR Jr, Parisi JE, et al: Characterization of frontotemporal dementia and/or amyotrophic lateral sclerosis associated with the GGGGCC repeat expansion in C9ORF72. Brain 2012, 135:765-783.

58. Majounie E, Abramzon Y, Renton AE, Perry R, Bassett SS, Pletnikova O, Troncoso JC, Hardy J, Singleton AB, Traynor BJ: Repeat expansion in C9ORF72 in Alzheimer's disease. N Engl J Med 2012, 366:283-284.

59. Snowden JS, Rollinson S, Thompson JC, Harris JM, Stopford CL, Richardson AM, Jones M, Gerhard A, Davidson YS, Robinson A, Gibbons L, Hu Q, DuPlessis D, Neary D, Mann DM, Pickering-Brown SM: Distinct clinical and pathological characteristics of frontotemporal dementia associated with C9ORF72 mutations. Brain 2012, 135:693-708.

60. Ikeda Y, Dalton JC, Moseley ML, Gardner KL, Bird TD, Ashizawa T, Seltzer WK Pandolfo M, Milunsky A, Potter NT, Shoji M, Vincent JB, Day JW, Ranum LP: Spinocerebellar ataxia type 8: molecular genetic comparisons and haplotype analysis of 37 families with ataxia. Am J Hum Genet 2004, 75:3-16.

doi:10.1186/alzrt133

Cite this article as: Schymick JC, Traynor BJ: Expanding the genetics of amyotrophic lateral sclerosis and frontotemporal dementia. Alzheimer's Research \& Therapy 2012, 4:30. 